\title{
Can evil create?
}

\section{Lévinas in conversation with the idea of tikkun olam and Kierkegaard}

\author{
Anna Westin
}

Aвstract - In this article, I look at the phenomenological expression of creativity through language as a way of relating to the self and others. Employing the Jewish concepts of the yetzerim, or impulses, philosophically, I suggest that these instances of existential engagement further develop the ethical act of tikkun olam, or the mending of the relational world. Moving beyond theodicies of good and evil, I will develop this account of relation by drawing on Emmanuel Lévinas's and Søren Kierkegaard's philosophy of subjectivity. I argue, therefore, that language can express particular accounts of relationality that can serve to clarify the ambiguous relationship between good and evil.

\section{An existential phenomenology of good and evil}

As humans, we often look to make sense of the given world around us, and the relation between others and ourselves. As philosophers, the task remains essentially the same, only we want to clarify the everyday situation further. Existential phenomenology lends itself well to this task, because it looks at how we, as subjects of consciousness, respond to the appearance of things and choose who we are becoming. These selfchoices are shaped by different interactions, some of which are ethically significant. Navigating our free choice, then, becomes a creative and ethical act that shapes who we are. In this article, the intent is to clarify the interaction between creativity and ethical action through the existential phenomenology of Emmanuel Lévinas and Søren Kierkegaard. This will be brought into conversation with the concepts of the yetzerim and tikkun olam that emerge in Jewish philosophy.

I will examine how the first person subject, as a free agent, engages in a series of choices.
These choices can either rupture or restore our relation to others and ourselves, but the distinction often borders on ambiguity. I will argue that this requires a creative exploration of evil, as experienced through the yetzer hara, or the break in relational expression. This phenomenon contrasts with the yetzer hatov, or the ethical life expression of relational mending, understood in tikkun olam. ${ }^{1}$ I will therefore suggest that understanding the creative phenomenon of language helps us to clarify the restoration and rupture of the ethical relation between the self and the other.

This particular discourse on the rupturing and healing potential of creative expression has emerged from reflections on a particular recent event. One afternoon, a songwriter friend and I were in the midst of a discussion on creative writing while crossing through our south

1 Here, olam may refer not only to the present world, but also to eternity, suggesting that the ethical response of the present links to a mending of a future world. 
London housing estate. We puzzled over how intricate, subtle and interconnecting pieces of writing were often created in the midst of deep personal pain. The isolating pain of this experience is what Lévinas refers to as mal, which is also translated as evil. ${ }^{2}$ It felt pertinent to discuss evil and creative expression in this particular context, as the golden afternoon sun softened the cement edges of buildings that had only days before witnessed a horrific suicide. We tried to connect the suffering of these events to the community we were in, and wondered whether creative expression could further tear or mend the relationship between inhabitants. It seemed to us that the use of language in certain pieces of writing intentionally relates the writer to the otherness of the world, while other pieces present a trapped self, a hidden face. ${ }^{3}$ The idea that the phenomenological experience of suffering could be expressed in language seemed not to be the question: we reeled off the countless artists and poets who had spoken out of this experience. Rather, it seemed to be the use of language for the purpose of relationship that revealed an ethical intentionality behind the words expressed.

I realise that there is a certain ambiguity to these claims. However, it is this phenomenological ambiguity that creates the complex task of understanding our existence alongside others: that is, how we experience ourselves and our lived interaction with others, and whether we can creatively use language to connect or disconnect ourselves from the goal of becoming ourselves alongside others. I suggest that understanding

2 Expressing the connection between $\mathrm{mal}$ and the sensation of pain as phenomenological experience of suffering, is based on Richard Cohen's translation of 'useless suffering' ( I988: I57).

3 For more on the use of poetry in medicine, see Trevor Stammers's article, 'Healing allusions? The use of poetry in teaching medicine' (2015). the particular impulses that produce phenomenological encounters with existence require looking at the speaker's intention of language, as it reflects how we construct our understanding of self-becoming alongside others.

This self-becoming can occur within a context experienced as suffering, where pain is a part of suffering (cf. Carel 2or6, and Merleau-Ponty I 9964). It is, of course, important to distinguish between the suggestion that physical pain is a part of the suffering experience and the suggestion that pain and suffering are equivalent. For instance, Eric Cassell writes that 'suffering must involve the whole person - bodies do not suffer, persons do' (2004: vii). Thus, the body in pain is a part of the human experience of suffering, but suffering cannot be equated merely with pain. In this argument I wish to make the link between suffering and the experience of evil. This means suggesting that a phenomenological instance of evil can directly affect our embodied interaction of the world. The complexity of suffering is therefore developed through examining the experience of good and evil. Evil and the good, I will suggest, are not only passively received; rather, free existence suggests that the subject participates in choosing the relation. Thus I focus on how the self might freely choose particular ways of expression through language, that express good and evil phenomenologically, through the rupturing or restoring of relation. This requires specifically looking at how evil can be caused by subjective agents. For this exploration, I use the existential phenomenological language of Lévinas and Kierkegaard, and briefly engage with Jewish philosophy.

4 'Bien entendu, tout ce que nous disons de la vie concerne en réalité la conscience de la vie, puisque nous qui en parlons sommes coscients. Cependant, la conscience ressaisit comme sa propre limite et sa propre origine ce que pourrait être la vie avait elle' (MerleauPonty I 996: 83). 


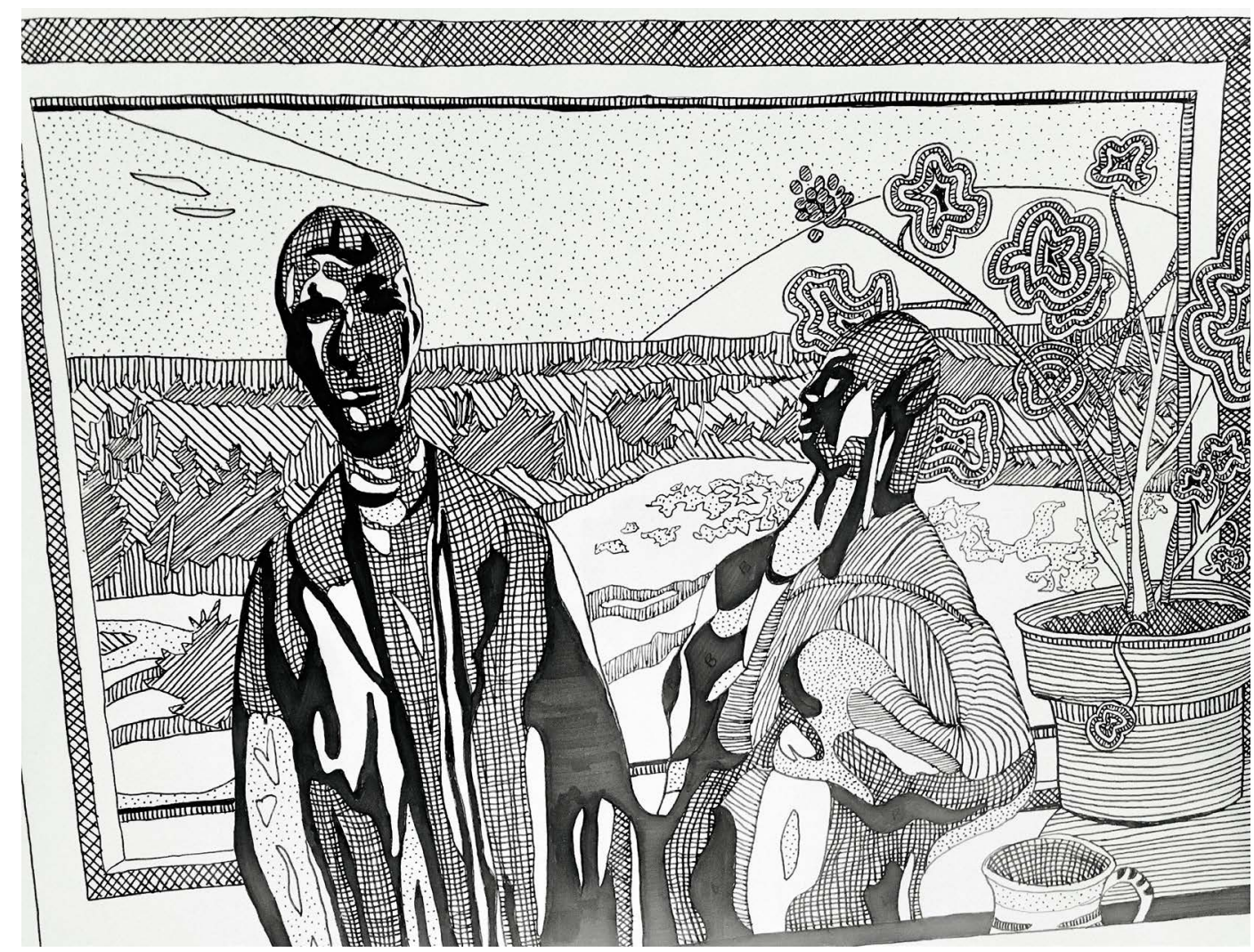

The Healing Room by John Paul Westin.

To start this discussion, let us first explore the use of language. To produce poetry, lyrics and literature requires bringing something from within the self into relation with the external world. Here, I am drawing from René Rosfort's helpful clarification, in which language is used in phenomenology to bring ambiguous experiences of consciousness, such as suffering, into articulation. Thus language 'enables us to seize the reins of, or at least some aspects of' an experience that can otherwise seem 'arbitrary' and 'affective' (Rosfort 2016: ro). Language thus emerges from a prior situated self-concept of the speaker.

However, a complex ambiguity is revealed when trying to determine who the self that uses language to articulate conscious experience actually is. In Jewish thought, the self is created with two impulses. Rather than Augustine's view that evil is simply the non-presence of the good, the Jewish notion seems more nuanced. Berel Lang shows how Jewish philosophy has long been interested in the account for the phenomenon of evil. He ties the experienced presence of evil to suffering and loss, which is held in tension with the experience of 'a world that is assumed to be ruled by goodness' (Lang 2007: 277). For instance, he suggests that the drama of Genesis reveals the free choice of humans enacting this paradoxical presence, by revealing free partnership with two inclinations (yetzarim). The first inclination is the yetzer hara, the evil inclination, or, as Lang explains, that which presents the possibility of the presence of evil (cf. ibid.). The other, the yetzer hatov, is the impulse for good. Insofar as the self is created, 'The character of a person is determined by which of the two impulses is dominant within him' (Cohen I 995: 
94). While both impulses exist within the self, a continuous engagement with the good brings this impulse to the fore. As such, this reveals the role of free will in the agency of the self. In Good and Evil, Martin Buber expounds on this concept by stating that the human passion generated by yetzer hara is included in the injunction of the Torah's wording that all of creation was declared 'very good' (Gen. I:3 I; Buber I952). Thus it is humanity, not God, that makes 'the so-called evil inclination evil', rather than a mere creative 'elemental force' (Rudavsky I 967: 240). Other writings suggest that the evil impulse was historically externalised in the representation of demons, while more modern interpretations have brought it into the psyche of the self, as inclination or desire (Rosen-Zvi 2008: $5 \mathrm{I} 4$ ).

For an agent to assume moral responsibility, it needs to be able to freely choose between states of consciousness. The consensus throughout the literature, therefore, is that the self has a certain amount of freedom in relation to the yetzer, and this engagement develops the character of the self. However, both impulses express different phenomenological relations. Choosing to act according to the yetzer hara divides the self from a self-unity, thereby acting against an original self-integration (Rosen-Zvi 2008: 526).5 Other scholars press the concept further in suggesting that choosing the good is intimately connected with the well-being of the self ('choose life', Deut. 30:19) and the wellbeing of others. Cohen, for instance, writes: 'The good impulse is accordingly identified with the moral consciousness' (2008: 95). Here it seems that engaging with the good impulse is a matter of reason and active choosing that is linked to responsive engagement towards others. It is not the choice of remaining as a solipsistic

5 This freedom to choose evil differs from Kierkegaard's concept of evil, and the Lutheran doctrine of the unfree will that is inclined towards $\sin$ (servum arbitrium) (Podmore 2009: I74). ego. Thus the development of the yetzer hatov impulse could be said to partner with and further express the general theme of tikkun olam in Jewish ethics. This requires consciously acting in such a way as to 'mend the world', responsibly, on behalf of the other.

\section{Lévinas, responsibility and suffering}

This concept of responsibility for the other as fundamental to the self-relation, while not spelled out as tikkun olam, is reflected in the phenomenology of Lévinas. Understanding the distinction between impulses, and the conscious engagement of responsibility in tikkun olam, can be a way of further clarifying what Lévinas means by living a life for the other. Lévinas's phenomenology developed an ethics of self towards the other, as an outworked response of the atrocities of the Shoah. For him, the self-other relationship defining ethics became the premise for his philosophical inquiry. Ethics is the first task of philosophy. His philosophy is thereby a universalised rendering of the command to respond. It is the individual subject, turning in response ( $m e$ voice, or 'here I am') towards the other (Lévinas I 998: I 46).

For Levinas, the good is enacted through ethics. Ethics here broadly refers to the relationship of responsibility to the other. It 'happens in and as language', through the après vous orientation of life towards the other (Robbins 200I: 4). It is experienced through the confrontation of each unique face that reveals to us a world that is outside ourselves (Sebbah 2000: 39). But this account of language requires further explanation, because Lévinas wishes to distinguish between the 'saying' (le dire) and the 'said' (le dit). Ethics is enacted not as symbol, but as an orientation towards the other, which can involve exposing oneself to suffering on the other's behalf. In Otherwise than Being, Lévinas reveals this orientation through the phenomenon of saying, which is 'a denuding of the unqualifiable 
one ... unique and chosen in an exposedness to the other' (I 998: 50). This saying is the ethical 'risky uncovering of oneself' (ibid.). But language, Lévinas explains, is often understood in terms of the ontological said: as a fixed assembly of essence that is 'thematised' and receives 'a title' (ibid. 42). This makes the other merely an abstract 'apparition', rather than one towards whom the subject is responsible. The difficulty with my account is that Lévinas wishes to locate art, and the poetic, in the said. The 'lived state' is fixed, and the 'Said is reduced to the beautiful', which Lévinas equates with Western ontology (ibid. 40). However, the saying is taken up in the said 6 and language becomes the means of articulating the 'proximity' of the other, which is where I think creative language can assume the ethical task. Here, in the saying, language can bring the other close to us, thereby bringing through poetry, as William Dyrness writes, as a means of 'paying attention' (2014: 25). This use of language requires something of the writer: it requires proximity and the risk of 'uncovering ... oneself' (Lévinas I 998: 50) before the other. This use of language would demand that the poet expresses himself or herself in giving, whilst also opening up the self to suffering for the other. ${ }^{7}$

There is therefore a duality to Lévinas's understanding of suffering. Suffering is a part of the experience of being for the other, understood as part of ethics. Yet we do not want the

6 Lévinas writes that it is the task of saying to awaken in the said the saying 'proximity which is absorbed in it' (1998: 43). The proximity of the saying is also expressed through gestures and sound, but for the purposes of this argument I will limit the discourse to language.

7 Whilst emerging from a similar discourse, Lévinas's invocation of suffering and exposure therefore presents a different approach to the poetic symbolism that Dyrness advocates in his article (2014: $2 \mathrm{I}-37$ ). other to suffer. This is evil, useless in itself. ${ }^{8}$ In some instances, for example, Lévinas shows how it can even overwhelm the bodily senses to such an extent that a person feels closed off from the outside world (I988: I56). So suffering is assumed on behalf of the other, as an instance of the good; yet in itself, divested of relationship, it can be experienced as an evil. Understanding its presence therefore does not mean a process of justification, or 'an imposed resolution' (Lang 2007: 295). Finding a theodicy for suffering does not make sense because it is so overwhelming that it cancels out meaning. ${ }^{9}$ Yet when, for example, a doctor jeopardises her own safety and comfort and assumes suffering to help the other, this instance reveals a trace of goodness through which ethics is phenomenologically revealed.

Understanding the relationship between language and suffering, as a phenomenological expression of evil and good, therefore reflects a deeper understanding of the subject. For Lévinas, prior to the development of a specific subjectivity, the ambiguous being is presented as the il y a (there is) (Perez 200I: 4). It is what Lévinas refers to as le mal, and impersonalité (200 I: I I 5-2 I). Le mal invokes horror as a state of being through its impersonality: there is no escape from oneself. Only as the self is revealed as limit, through the confrontation of the other, can it become itself as an ethical subject. Ethics, and the possibility of suffering, along with the responsibility towards the other who suffers, brings the self out of itself, towards and for the other. 10

8 'Suffering is surely a given in consciousness, a certain "psychological content", like the lived experience of colour, of sound, of contact, or like any sensation' (Lévinas I 988: I 56 , italics in the original).

9 Lévinas writes: 'Thus the least one can say about suffering is that in its own phenomenality, intrinsically, it is useless, "for nothing", (I 988: I 57-8).

10 Lévinas thereby criticises Husserl's understanding of the 'alter ego', suggesting that the 
When the other speaks to me, they reveal something beyond my self-enclosure. The other exposes a goodness that is beyond me, and presents me with the experience of an infinite otherness, outside me. Language is used to communicate this unknown other to me. It communicates an otherness that I respond to. I am given an escape out of myself. So language here is a part of the phenomenological character of ethics, communicating, through the outer call of the other and the inner response of the self. It is what reveals the hiddenness of the other that is separate from me. It brings me out of my egoism into the place of receiving from another. Both good and evil provide options for being, but the use of language is different. Only one connects the self towards the revelation of the other. Evil is experienced as the ego's solipsism (Lévinas 200I: 4-5). Goodness manifests itself in the infinite and responsive exchange towards the other.

\section{Kierkegaard, language and relation}

This phenomenological use of language is similarly assumed in Kierkegaard's writings on anxiety. Contrary to the Jewish understanding of the free will that can choose between the yetzerim, Kierkegaard writes out of the Lutheran context of original sin (Podmore 2009: I74), where the self is paradoxically entangled and free. In Either/Or (I 843), Kierkegaard writes that 'against God we are always in the wrong' (Kierkegaard 1992: 60I). Thus the self has the choice 'between being nothing before God and the eternal torment of constantly beginning over again yet without being able to begin' (ibid.). Here, suffering is tied to the existential phenomenon of a self that chooses to become itself.

In The Concept of Anxiety ( I 844), Kierkegaard writes that anxiety is experienced as the self

other is completely distinct from us (Roesner 2016:33). increasingly realises its freedom and finitude. While Kierkegaard seems uninterested in figuring out theodicies for why evil happens, 11 he is interested in mapping out the different existential experiences. For Kierkegaard, goodness manifests itself in the self that becomes itself. This culminates in an integrated self that engages with others. Evil, then, as expressed in Either/Or and The Concept of Anxiety, emerges as divided self-becoming. For instance, in Kierkegaard's Upbuilding Discourses ( 1843 ), he writes: 'Is not evil, just like evil people, at odds with itself, divided in itself?' (Kierkegaard I993: 34). This is seen in Either/Or, where the aesthete's varying moods, conditioned by external situations, mean that he cannot choose to become himself with any consistency (Kierkegaard I980: 20I). Here, 'the total mood therefore constantly resounds in the particular mood, creating its resonance in the form of impotence and vapidity' ( 1980 : 206). Thus, Kierkegaard's evil is revealed in the existential state of mis-choosing oneself. This differs from 'the good man' who is 'at one with himself and at one with all, because he wills one thing and because the good is one thing' (Kierkegaard I993: 34f).12 In Either/Or, the 'moment of choice' involves choosing oneself, or 'put[ting] on oneself', which means that there is a unified consciousness of 'responsibility for oneself' (Grøn 2013: 282; Kierkegaard 1 992: 248). This chosen self-unity becomes a manifestation of the good self-relation.

In The Concept of Anxiety and Either/Or, we see how Kierkegaard's self experiences the

11 For example, see Claudia Welz's comparison of the treatment of theodicy in Kierkegaard and Lévinas in 'Reasons for having no reason to defend God' (2007).

12 Joakim Garff suggests that the Upbuilding Discourses are thereby used to 're-build' and 're-form the self-understanding' from the defective one that the pseudonymous texts have uncovered (2013:266). 
phenomenon of anxiety when it opens itself up to the possibility of becoming an individual, a paradoxical synthesis of infinity in finite form. Similarly to Lévinas, the good is 'a conception ... that can never become an object of knowledge' (Welz 20r3: 452). Yet, as revealed in the phenomenological concept of God, the relation to the good redeems the entanglement of freedom and unifies the paradoxical self-relationship (Kierkegaard I980: 140). It is the possibility of a unification that brings rest.

Instead of opening the self up to the possibility of freedom, evil13 manifests itself as a self-enclosing. Thus Kierkegaard's pseudonym Haufniensis writes that it 'is an unfree relation to the good', a 'protest against the good' (I980: II9). It is what Dunnington describes as a 'withdrawnness', which 'closes up itself within itself' (1985: 26-7). It is 'the contentless, the boring' (ibid.). Yet, as Grøn points out, the relationship to the good is a decision made despite the appearance of things (2008: I 52), for, as the pseudonyms have told us, the appearance is often deceptive. For Kierkegaard, evil emerges through encountering the good and choosing to assert oneself against this relation. However, because for Kierkegaard, the self's relation to the good becomes the grounds for a self-integration, as the self asserts its autonomy against this relation to the good, it is also alienating itself from self-integration. This creates a conflicted self. The self is not dependent on the good, but only on itself. Louis Dupré writes that the relation to the good is 'at the very heart of the self' (I977: 49). Yet in asserting this, the self is divided and cannot sustain its self-integration.

One of the ways that this 'withdrawnness' into oneself is manifested concretely is in the use of language. In Kierkegaard, language is the phenomenon through which we relate this

13 In The Concept of Anxiety, Haufniensis refers to the evil of enclosure through the experience of the demonic (Kierkegaard I 980: 27). subjective experience to others, thereby presupposing a 'communal context' (Hall I 985: I 54). Language presupposes a freedom, because it requires an integrated self to articulate itself: it requires 'an integrity of expression and behaviour of the outward and the inward' (ibid. I 58 ). The opposite would be what Kierkegaard refers to as the self-enclosed (indesluttede) of the enclosing reserve.

Language can therefore be chosen to serve the goal of freedom, which is a self opening itself up to reveal its internally integrated self-expression externally: 'Freedom is precisely expansive' (Kierkegaard I980: I23). Ronald Hall, interpreting Kierkegaard, suggests that

when a person speaks as himself, there is an integrity of expression and meaning, what is expressed, that which originates (inwardly) in a freely chosen intention of the speaker. When a person speaks as himself, he takes full responsibility for what he has said as his own. Such expression is no longer deception. (Hall I 985: I6I)

It seems here, then, that the relation to the other, in which the subject has freely chosen itself, and exists in community with others, requires language. Language that communicates this self and social integration is taken up in the act of responsibility. I am sharing of myself by communicating myself to you. This is a part of what resting in the good expresses. However, the enclosed self 'does not want communication' (Kierkegaard I 980: 124). Kierkegaard writes that this phenomenon expresses itself as 'a muteness. Language, the word, is precisely what saves the individual from empty abstraction of enclosing reserve' (ibid.), and makes us responsible for what has been said. Thus the person hides away within him- or herself, though this self is without unity, whereas the good, expressed as self-integration in language, asserts a continuous, responsible expression of subjectivity in relation. 


\section{Language and relation in good and evil}

What parallels, then, can we draw from these two thinkers' accounts? I would suggest that both develop two central ideas. Firstly, evil is understood in phenomenological relation to the subject and relation to the other. For Lévinas, it is expressed through the concept of responsibility and suffering. For Kierkegaard, it is through the self that the individual chooses itself in paradoxical union. The choice between good and evil therefore expresses itself through the experience of self-becoming, while also connecting the subject to other people. In Lévinas, we see this through the call to respond, and the vulnerability of exposure. For Kierkegaard, the united self reveals itself, for instance, in acts of love done towards the other (I990: 80). The phenomenon of evil withdraws the subject from engaging with this other-relation, in an integral and responsible way. Secondly, this relation is experienced through language. Whereas the il $y a$ and the lost self are enacted in self-enclosure, the good engages towards the other, thereby communicating itself to other. It speaks, and what is spoken externally articulates (for Kierkegaard at least) a subjective integration. For Lévinas, it opens us up to the other who is beyond us, and asserts us as subject.

While it would be problematically reductive to equate Lévinas's phenomenology of the il y a with Kierkegaard's subjective experience of lostness, some interesting points are raised in both that are worth further consideration. The first is how language can be used to express the ambiguous existential phenomenology of a self in relation to the world. The second is, then, whether language used in this way can help us to 'mend the world'. That means that the phenomenological expression of language becomes the means through which the yetzer hara and yetzer hatov are expressed. I have suggested that the presence of good and evil, as potentialities, require a phenomenological account of self. This is developed and nurtured through responsibility and choosing a continuously communicated self-integration.

I am therefore suggesting that Lévinas's and Kierkegaard's understanding of relation can help to develop the Jewish concept of tikkun olam, which the yetzer hatov facilitates. ${ }^{14}$ This is the concept of the act of 'mending the world', through a responsible engagement with life. If we take this understanding, I would suggest that using language as an articulation of the good, of integrated self-relation, of an expanding towards the other, could be a tool to engage with tikkun olam. Thus, choosing to engage the creative impulse within the movement of language that connects the self to another, it can serve as a response from an integrated rather than a deceptive self-other relationship, a relationship of responsibility rather than harm, an expansive and continuous self. Language, however, consists of different expressions. For Kierkegaard, it is the verbal language that partly discloses the inwardness of subjectivity (Shakespeare 2013: 59 ). It goes beyond the immediacy of what is given, but is required as a mediator of intersubjective reality (ibid.). For Lévinas, language reveals the ethical phenomenon of saying in the said, which can be revealed through verbal as well as physical expressions. Both show how language can be used to phenomenologically express relation. It can be a withdrawn hostility towards the other or it can phenomenologically express an articulation of the ethical good.

Evil then, while being capable of creative expression, in the understanding of the yetzer hara impulse, essentially encloses expression.

14 I think this is similar to the Jewish reading of Lévinas that Claire Elise Katz facilitates in Lévinas and the Crisis of Humanism, when she writes that 'we can see for Lévinas, holiness, or religiousness, is in fact the accomplishment of the ethical - and the ethical described very specifically as the response to the Other' (20I3: 72). 
Words are formed, but the words in their content do not expand the self towards the other or create access to the 'beyond' of the ethical saying. The self is encapsulated within itself. Whether or not we can see this in creative expression is, of course, the real challenge in applying this theory. Yet is this not what writers consistently try to express? Poets try to find words to bring the experience of suffering into a meaningful connection, as an articulation of the good. Writers create plots that bring the self out of isolation and into connection with the other. The integrity of a self that communicates to connect enables language to express a free response towards the exterior world. It reveals a face to us beyond ourselves. Consequently, language becomes a phenomenon in which the mending of relation, the act of tikkun olam, can occur.

To illustrate this by way of conclusion, I find the simple language of this child's poem, written by Pavel Friedman while he was held in the Terezin concentration camp, particularly illustrative. He writes:

The last, the very last,

So richly, brightly, dazzlingly yellow.

For seven weeks I've lived in here,

Penned up inside this ghetto

But I have found my people here ...

Only I never saw another butterfly.

(Friedman 1978: 33)

Here, communicating his face to us, he connects us to responsibility and response. He reveals an experience beyond our own present. Through his use of language, we are drawn into relation and response, and thereby an encounter with the good. This self-expression, whilst articulated in the midst of suffering, thus becomes a response and a message outwards.
Anna Westin, BA, Dip. Appl.Ethics, Mag., MA, PG Cert. HE, Ph.D., has completed a Ph.D. in the philosophy of addiction, engaging in the existential and phenomenological approach of Kierkegaard and Levinas at St Mary's University, London, under

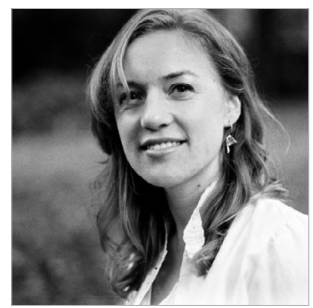
the supervision of Dr Hannah Marije Altorf and Dr Pia Matthews. She has published in places such as the Journal of Medical Ethics and the New Bioethics Journal and has acted as visiting lecturer at Richmond, The American University in London and St Mary's University. Westin is currently a visiting lecturer at the London School of Theology and St Mary's University. She is also involved in various independently affiliated research projects and has been actively engaged in society memberships outside the university.

\section{Bibliography}

Buber, Martin, I952, 'Images of good and evil', Good and Evil: Two Interpretations (New York, Charles Scribner's Sons)

Carel, Havi, 2016. Phenomenology of Illness (Oxford University Press)

Cassell, Eric, 2004. The Nature of Suffering and the Goals of Medicine (Oxford University Press)

Cohen, Abraham, I 995. Everyman's Talmud: The Major Teachings of the Rabbinic Sages (New York, Random House)

Dunnington, Stephen, I985. 'Kierkegaard's systematic analysis of anxiety', IKC: The Concept of Anxiety, ed. Robert Perkins (Macon, GA, Mercer University Press), pp. 7-34

Dupré, Louis, 1977. A Dubious Heritage: Studies in the Philosophy of Religion after Kant (New York, Paulist Press)

Dyrness, William, 201 4. "Prophesy to these dry bones": the artist's role in healing the earth', Tikkun Olam: To Mend the World, ed. Jason Goroncy (Eugene, OR, Pickwick Publications), pp. 22-36

Friedman, Pavel, I 978. I Never Saw Another Butterfly (New York, Schocken Books)

Garff, Joakim, 2013. 'Formation and the critique of culture', The Oxford Handbook of Kierkegaard (Oxford University Press), pp. 252-72

Grøn, Arne, 2008. The Concept of Anxiety in Søren Kierkegaard, trans. Jeanette B. L. Knox (Macon, GA, Mercer University Press)

2013. 'Time and history', The Oxford Handbook of Kierkegaard (Oxford University Press), pp. 273-9I 
Hall, Ronald, I 985 . 'Language and freedom: Kierkegaard's analysis of the demonic in The Concept of Anxiety', IKC: The Concept of Anxiety, ed. Robert Perkins (Macon, GA, Mercer University Press), pp. I 53-66

Katz, Claire Elise, 20I 3. Lévinas and the Crisis of Humanism (Bloomington, Indiana University Press)

Kierkegaard, Søren, I 980. The Concept of Anxiety, trans. Reidar Thomte (Princeton University Press)

- i 990. Works of Love (New York, Harper Collins)

- I992. Either/Or, trans. Alistair Hannay (London, Penguin)

- 1993 . Upbuilding Discourses in Various Spirits: Kierkegaard's Writings XV, ed. and trans. Howard V. Hong and Edna H. Hong (Princeton University Press), pp. I-I 54

Lang, Berel, 2007. 'Evil, suffering, and the Holocaust', The Cambridge Companion to Modern Jewish Philosophy, eds Michael Morgan and Peter Gordon (Cambridge University Press), pp. 277-99

Lévinas, Emmanuel, I 988. 'Useless suffering', The Provocation of Lévinas, eds Robert Bernasconi and David Wood (Pittsburgh, PA, Dusquesne University Press), pp. I 56-67

- 1998 . Otherwise than Being, trans. Alphonso Lingis (Pittsburgh, PA, Duquesne University Press)

-200 . Existence and Existents, trans. Alphonso Lingis (Pittsburgh, PA, Duquesne University Press)

Merleau-Ponty, Maurice, I 996. Sens et Non-Sens (Paris, Éditions Gallimard)

Perez, Félix, 200I. D'une aensibilité a l'autre dans la pensée d'Emmanuel Lévinas (Paris, L'Harmattan)

Podmore, Simon, 2009. 'Kierkegaard as the physician of the soul: on self-forgiveness and despair', Journal of Psychology and Theology, 37(3), pp. I74-85

Robbins, Jill, 200 . 'Introduction', Is It Righteous to be? Interviews with Emmanuel Lévinas (Stanford University Press), pp. I-22

Roesner, Martina, 2016. 'The nudity of the ego: an Eckhartian perspective on the Lévinas/ Derrida debate on alterity', The Journal of the British Society for Phenomenology, 47 (I), pp 33-55 <https://doi.org/I0. I080/0007 I 773.20 I 5 .I I $10088 \mathrm{I}>$

Rosen-Zvi, Ishay, 2008. 'Two rabbinic inclinations? Rethinking a scholarly dogma', Journal for the Study of Judaism, 39, pp. 5 I 3-39

Rosfort, René, 20i6. 'The struggle with words: language and emotion', Journal of Psychopathology, 22, pp. 10-20

Rudavsky, David, I967. Emancipation and Adjustment (New York, Diplomatic Press)

Sebbah, François-David, 200o. Lévinas (Paris, Les Belles Lettres)

Shakespeare, Steven, 2013. Kierkegaard, Language and the Reality of God (Columbus, OH, Biblio Publishing)

Stammers, Trevor, 20 15. 'Healing allusions? The use of poetry in teaching medicine', Journal of Contemporary Medical Education, 3(3), pp. I $27-33$

Welz, Claudia, 2007. 'Reasons for having no reasons to defend God: Kant, Kierkegaard, Lévinas and their alternatives to theodicy', Wrestling with God and with Evil: Philosophical Reflections, ed. Hendrik Vroom (Amsterdam, Editions Rodopi), pp. I67-86 2013. 'Kierkegaard and phenomenology', The Oxford Handbook of Kierkegaard (Oxford University Press), pp. 440-63 